\title{
Individual and genetic task specialization in policing behaviour in the European honeybee
}

\author{
Ulrich R. Ernst ${ }^{\text {a, b, * }}$, Dries Cardoen ${ }^{\text {a, b, } 1}$, Vincent Cornette ${ }^{\mathrm{a}, 2}$, Francis L. W. Ratnieks ${ }^{\mathrm{c}}$, \\ Dirk C. de Graaf ${ }^{\mathrm{d}}$, Liliane Schoofs ${ }^{\mathrm{a}}$, Peter Verleyen ${ }^{\mathrm{a}, 1}$, Tom Wenseleers ${ }^{\mathrm{b}}$ \\ ${ }^{a}$ Research Group of Functional Genomics and Proteomics, Department of Biology, KU Leuven, Belgium \\ ${ }^{\mathrm{b}}$ Laboratory of Socioecology and Social Evolution, Department of Biology, KU Leuven, Belgium \\ ${ }^{c}$ Laboratory of Apiculture and Social Insects, School of Life Sciences, University of Sussex, Falmer, U.K. \\ d Laboratory of Molecular Entomology and Bee Pathology, Department of Biochemistry and Microbiology, Ghent University, Ghent, Belgium
}

\section{A R T I C L E I N F O}

\section{Article history:}

Received 26 October 2016

Initial acceptance 8 December 2016

Final acceptance 13 March 2017

MS. number: 16-00943R

\section{Keywords:}

conflict resolution

division of labour

honeybees

patriline

reproductive conflict

social insects

worker policing
Cooperation in biological systems is frequently maintained by social enforcement mechanisms, where individually egoistic and group-costly behaviour is mutually suppressed by other group members. One of the best examples in nature is worker policing in the honeybee, Apis mellifera, where workers selectively remove or 'police' eggs laid by workers that egoistically try to produce their own offspring instead of working for the good of the colony. It has long been suggested that worker policing behaviour should be genetically determined, as theory has shown that queen polyandry in the honeybee would be expected to give rise to clear indirect genetic or 'inclusive fitness' benefits of worker policing, thereby causing genes for policing to spread in the population. In the present study, we tested the theory that worker policing should have a genetic component by determining whether workers belonging to different patrilines, derived from different fathers, differ in their tendency to police eggs. This analysis showed that variation in policing behaviour indeed has a genetic basis, with the trait having an estimated broadsense heritability of 0.25 ([0.013-0.46] 95\% confidence limits). In addition, there was clear individual specialization in policing, as just a few individuals within each patriline were observed to police. Remarkably though, there was no evidence for age specialization, as workers of all ages, except those younger than 10 days and older than ca. 40 days, engaged in policing. This contrasts with most other behaviours in the honeybee, which usually follow a strict age-linked pattern of division of labour. Overall, we conclude that worker policing behaviour in the honeybee is genetically heritable and that workers of all ages engage in policing to help maintain the social order in the colony.

๑) 2017 The Association for the Study of Animal Behaviour. Published by Elsevier Ltd. All rights reserved.
In the evolution of life on earth, natural selection has resulted in several so-called 'major transitions in evolution', where previously independently reproducing units teamed up, in some cases even giving rise to 'obligate cooperation', where the higher entities lost the ability to reproduce without the help of their subunits Bourke, 2011; Maynard Smith \& Szathmary, 1995). Examples include the cooperation between previously independently reproducing bacteria in the origin of the eukaryotic cell, the joining up of cells in the

\footnotetext{
* Correspondence: U. R. Ernst, Research group of Functional Genomics and Proteomics, Department of Biology, KU Leuven, Naamsestraat 59, PO Box 2465, 3000 Leuven, Belgium.

E-mail address: Uli.Ernst@bio.kuleuven.be (U. R. Ernst).

1 Present address: Toxikon, Romeinse straat 12, 3001 Heverlee, Belgium.

2 Present address: Covance Clinical \& Periapproval Services, Marcel Thirylaan 77, 1200 Sint-Lambrechts-Woluwe, Belgium.
}

origin of multicellular organisms, and the cooperation between individuals in highly advanced societies, such as those of the social insects (Maynard Smith \& Szathmary, 1995; Queller \& Strassmann, 2009). The long-term maintenance of cooperation in these systems, however, frequently requires social coercion and mutual policing mechanisms in order to suppress conflict caused by the expression of individually selfish but group-costly behaviour (Frank, 2003; Rainey \& De Monte, 2014; Ratnieks, Foster, \& Wenseleers, 2006; Ratnieks \& Wenseleers, 2008).

A prime example of such conflict-reducing policing behaviour occurs in several independently evolved lineages of social insects, including honeybees, ants, wasps and bumblebees, and is known as 'worker policing'. Worker policing is the behaviour where workers selectively destroy eggs laid by 'rogue' workers that, instead of helping to rear the queen's brood, decide to try to reproduce by depositing unfertilized, male-destined eggs (Ratnieks \& Visscher, 
1989; Wenseleers \& Ratnieks, 2006a). Worker reproduction can be in the genetic interests of individual workers, as each is more related to its own sons $(r=0.5)$ than to the sons of the queen (brothers, $r=0.25$ ) (Ratnieks et al., 2006; Wenseleers, Helantera, Hart, \& Ratnieks, 2004). Yet, theory also predicts that collective workers' interests should frequently oppose such individually egoistic behaviour, and that workers can be selected to try to prevent other workers from reproducing, either by attacking workers with developed ovaries (e.g. Dampney, Barron, \& Oldroyd, 2002; Visscher \& Dukas, 1995) or by eating eggs laid by other workers (reviewed in Wenseleers \& Ratnieks, 2006a).

The reasons that worker policing behaviour can be selected for are varied, and at a theoretical level this behaviour can be caused by worker reproduction resulting in too many males being reared (Foster \& Ratnieks, 2001b), worker male production being traded off against long-term colony growth, (Ohtsuki \& Tsuji, 2009; Ratnieks, 1988; Wenseleers, Helantera, Alves, Duenez-Guzman, \& Pamilo, 2013), reproductive workers working at a reduced rate (Dampney, Barron, \& Oldroyd, 2004; Wenseleers, Helentra et al., 2004; but see Naeger, Peso, Even, Barron, \& Robinson, 2013), worker-laid eggs being less viable than queen-laid ones (Pirk, Neumann, Hepburn, Moritz, \& Tautz, 2004; but see Beekman \& Oldroyd, 2005; Helanterä, Tofilski, Wenseleers, \& Ratnieks, 2006), workers obtaining direct reproductive benefits from policing ('selfish worker policing', Bonckaert et al., 2011; Saigo \& Tsuchida, 2004; Stroeymeyt, Brunner, \& Heinze, 2007; Wenseleers, Tofilski, \& Ratnieks, 2005), worker policing being targeted against genetically unrelated worker reproductive parasites (Beekman \& Oldroyd, 2008; Pirk, Neumann, \& Hepburn, 2007; Zanette et al., 2012), or workers obtaining indirect genetic benefits if the colony kin structure is such that workers are less related to the sons of other workers (nephews) than to the sons of the queen (brothers) (Ratnieks, 1988; Starr, 1984; Wenseleers \& Ratnieks, 2006a; Wenseleers, Tofilski et al., 2005).

This last theory, which is based on the presence of indirect genetic or 'inclusive fitness' benefits (Hamilton, 1964) and is known as the relatedness theory of worker policing, has perhaps received most attention, and applies when the mother queen is mated to two or more males or when the colony is headed by several related queens (Ratnieks \& Wenseleers, 2008). The classic example is the honeybee, Apis mellifera, where queens mate with about 10 males, which causes workers to be genetically more related to the queen's sons (brothers, $r=0.25$ ) than to the sons of other workers (a mix of full- and half-nephews, $r=0.15$ ) and where, as predicted, workers effectively police any eggs laid by other workers (Ratnieks \& Visscher, 1989) or attack workers with developed ovaries (Dampney et al., 2002; Visscher \& Dukas, 1995). Similar behaviour has been observed in many other social insect species, including in ants (e.g. D'Ettorre, Heinze, \& Ratnieks, 2004; Dijkstra, van Zweden, Dirchsen, \& Boomsma, 2010; van Zweden, Fürst, Heinze, \& D'Ettorre, 2007), wasps (e.g. Bonckaert et al., 2008; Foster \& Ratnieks, 2001a; Oi et al., 2015; Wenseleers, Tofilski et al., 2005), bumblebees (Zanette et al., 2012) and Asian honeybees, Apis cerana (e.g. Oldroyd et al., 2001), and, as predicted, has been shown to be disproportionately common in species in which collective relatedness disfavours worker reproduction (Wenseleers \& Ratnieks, 2006a). Effective policing has also been shown to act as a deterrent against attempting to reproduce (Wenseleers, Hart, \& Ratnieks, 2004; Wenseleers, Helentra et al., 2004; Wenseleers \& Ratnieks, 2006b). In the honeybee, for example, more than $98 \%$ of all worker-laid eggs are eaten by other workers (Ratnieks \& Visscher, 1989) and, consequently, only about one in 10000 workers develop their ovaries in the presence of the queen (Ratnieks, 1993).

Although worker policing behaviour in the honeybee is cited in all major behavioural ecology textbooks as providing classic support for the theory of inclusive fitness (Davies, Krebs, \& West, 2012; Dugatkin, 2009), and the logic that a gene for worker policing would be expected to spread in honeybee populations due to indirect genetic benefits is undeniable, it remains entirely untested to what extent policing behaviour does indeed have a genetically heritable basis. In fact, hardly any detailed observational studies have been published about honeybee policing behaviour. This contrasts with the detailed and generally available knowledge about division of labour in the honeybee which appears to be partly genetically based and partly linked to age ('age polyethism'; e.g. Calderone \& Page, 1988; Hunt, Page, Fondrk, \& Dullum, 1995; Johnson, 2010; Oldroyd \& Thompson, 2006; Oxley, Spivak, \& Oldroyd, 2010; Robinson, 1992; Robinson \& Page, 1989; Seeley, 1995; Smith, Toth, Suarez, \& Robinson, 2008; Winston, 1987). In the honeybee, genetic control typically expresses itself in large differences between patrilines in the degree to which workers engage in carrying out a particular task (Calderone \& Page, 1988; Oldroyd \& Fewell, 2007; Oldroyd \& Thompson, 2006), which has, for example, been shown in the context of specialization in pollen versus nectar foraging (e.g. Hellmich, Kulincevic, \& Rothenbuhler, 1985), undertaking and guarding (e.g. Robinson \& Page, 1988; Trumbo, Huang, \& Robinson, 1997) or hygienic behaviour towards dead brood (e.g. Pernal, Sewalem, \& Melathopoulos, 2012).

The aim of this study was two-fold. First, we carried out detailed behavioural observations of honeybee policing behaviour using a newly developed observation hive set-up and quantified the degree to which policing behaviour varies across different patrilines. In this way, we were able to infer whether honeybee policing is indeed partly genetically heritable (Ratnieks, 1988). Second, we determined whether, within each patriline, individual workers also specialize in carrying out policing behaviour, and whether, as is generally the case for other tasks in honeybees (Seeley, 1982), the expression of policing behaviour is restricted to a particular age cohort. Previously, individual task specialization in policing has been demonstrated in only a handful of species (in the ants Pachycondyla inversa (van Zweden et al., 2007) and Platythyrea punctata (Barth, Kellner, \& Heinze, 2010) and the vespine wasp Dolichovespula norwegica (Bonckaert et al., 2011), but age specialization has not been investigated in any of these. Finally, we linked the results we obtained to adaptive theories on optimal task allocation and division of labour in insect societies (Duarte, Weissing, Pen, \& Keller, 2011; Goldsby, Dornhaus, Kerr, \& Ofria, 2012).

\section{METHODS}

\section{Observation Hive Set-up}

Experiments were performed at the beekeeping facility of the University of Ghent (Belgium) in 2009 and were then replicated once more at the beekeeping facility of the KU Leuven (Belgium) in 2010. Below, we refer to these colonies as colonies 1 and 2. In each year, a colony of $A$. $m$. carnica with a naturally mated queen was housed in a three-frame observation hive kept inside at room temperature (Fig. 1a). The observation hive was connected to the outside via a plastic tube to allow bees to forage freely. The queen was not restricted in any way, but brood was removed regularly before bees emerged. Each day, we marked 100 newly emerged bees individually using a combination of numbered bee tags (Opalithplättchen, Graze, Weinheim, Germany, and Ewa Podlewska, Fabianki, Poland) and acrylic paint marks on their abdomens (Amsterdam All Acrylics, standard series, Royal Talens, Apeldoorn, The Netherlands, and deco craft, Lefranc \& Bourgeois, Le Mans, France). These bees were offspring of an unrelated, naturally mated queen and were obtained by placing a sealed brood comb in an incubator at $34^{\circ} \mathrm{C}$ under high relative humidity, after which all 


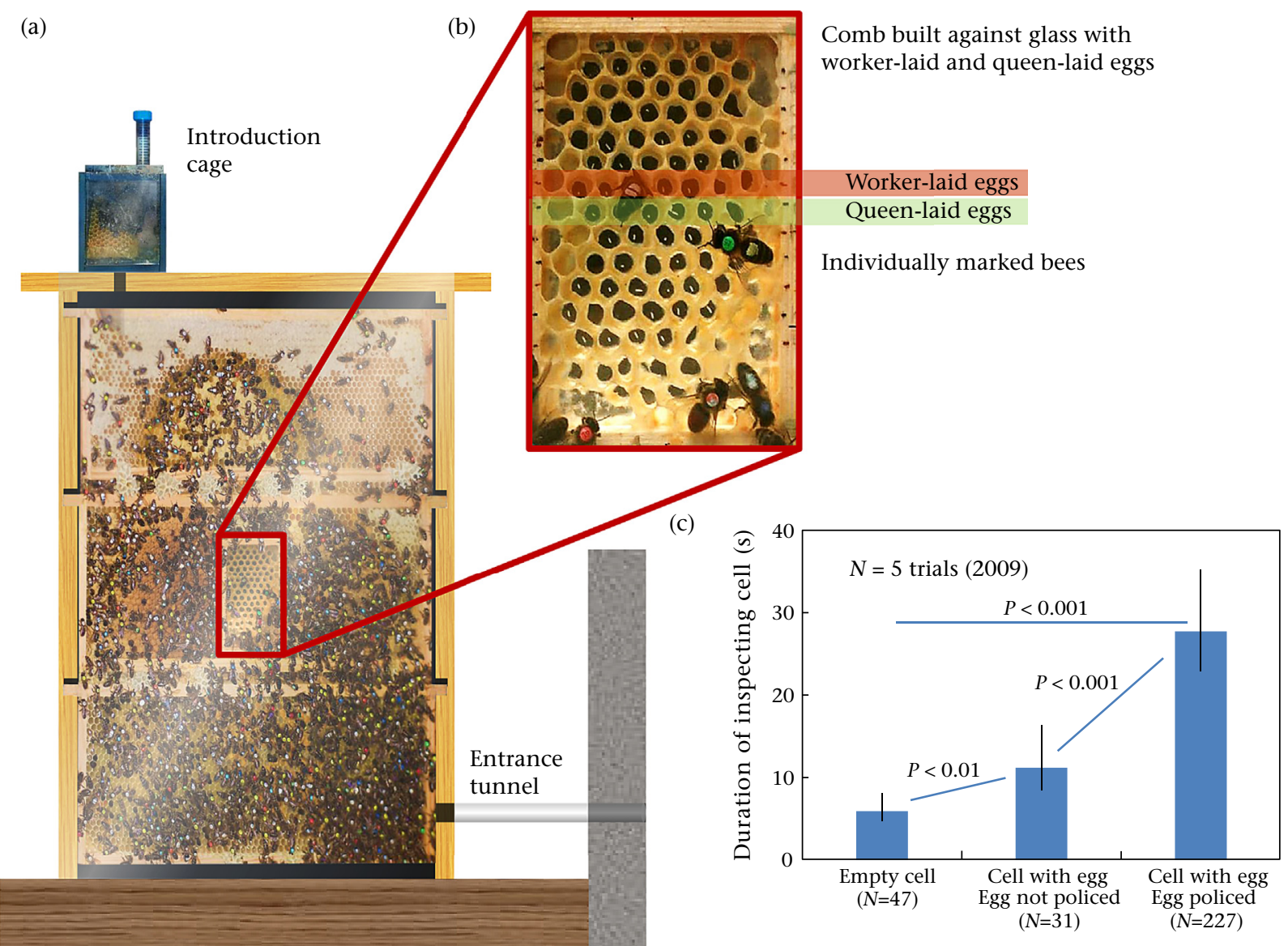

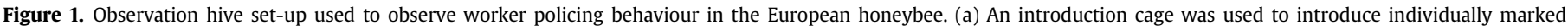

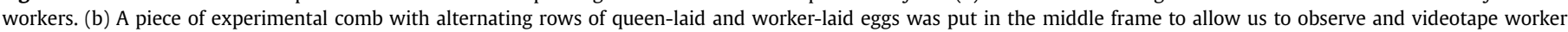

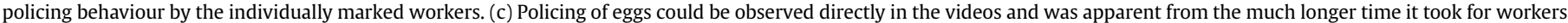
to police eggs compared to merely inspecting cells (inset, means, 95\% confidence limits and $P$ values based on a gamma GLMM).

bees that emerged were removed daily. Marked bees were kept overnight in a chamber placed on top of the observation hive, which was separated by a wire mesh from the inside, to allow bees to acquire the host colony's odour (Seeley, 1995), and were allowed to enter the colony the next day. By continuing this procedure for several weeks before and throughout the experiment, we ended up with observation hives in which virtually all bees were individually labelled and of known age.

\section{Observation of Policing Behaviour}

To observe policing behaviour, we carried out several repeated policing trials of $2 \mathrm{~h}$ each per observation colony until we had data on policing behaviour by ca. 20 individually marked workers per colony (Fig. 2; total number of trials $=3$ and 11 for colonies 1 and 2, respectively, carried out over a period of at most 2 weeks apart). At the start of each trial, we transferred worker-laid eggs $(N=33-69$ per trial) and queen-laid eggs $(N=33-69$ per trial) using modified Taber forceps (Taber, 1961) into alternating rows of a piece of experimental comb (ca. $9.5 \times 7 \mathrm{~cm}^{2}$ ) that was built by bees against a glass plate, thereby allowing for the easy observation of worker egg removal. This experimental comb was placed in the observation hive close to the brood, to allow bees of all ages easy access to the eggs (Fig. 1). Queen-laid eggs and worker-laid eggs were obtained from several unrelated queenless and queenright colonies. Subsequently, during each trial, bee behaviour was recorded for $2 \mathrm{~h}$ with a high-definition camera (Panasonic HDC-HS 300K) and videos were analysed in detail to determine the identity and age of all workers that policed eggs. During the analyses of the recordings, observers were ignorant of egg source (worker-laid eggs versus queen-laid eggs) and age of the workers. Descriptive data on the time required to inspect empty cells, inspect cells with eggs or police eggs were obtained from five trials carried out using the colony from 2009, and the durations were compared using a gamma generalized linear mixed model (GLMM) and Tukey post hoc tests, with individual coded as a random factor, type of event coded as a fixed factor and bee age included as a covariate. These analyses were performed using packages lme4 and multcomp in $\mathrm{R}$ version 3.3.2 (The R Foundation for Statistical Computing, Vienna, Austria, http://www.r-project.org; see Supplementary material 1).

\section{Microsatellite Genotyping}

To quantify between-patriline variation in policing behaviour and estimate the heritability of the trait, at the end of the experiment we collected all bees that had been observed policing $(N=18$ and 26 for colonies 1 and 2) as well as a random set of control bees that had been observed at least 10 times in our videos but which had never been observed to police eggs ( $N=184$ and 152 for colonies 1 and 2) and assigned them to particular father lines using microsatellite genotyping. To this end, the colony in the observation hive was anaesthetized with $\mathrm{CO}_{2}$ after which the DNA of the identified policing and nonpolicing bees was extracted following a modified Chelex-method (Walsh, Metzger, \& Higuchi, 1991) in which a hind leg was crushed with a pestle in liquid nitrogen, $200 \mu$ l of a hot Chelex 100 suspension (10\%, Biorad) was added, 


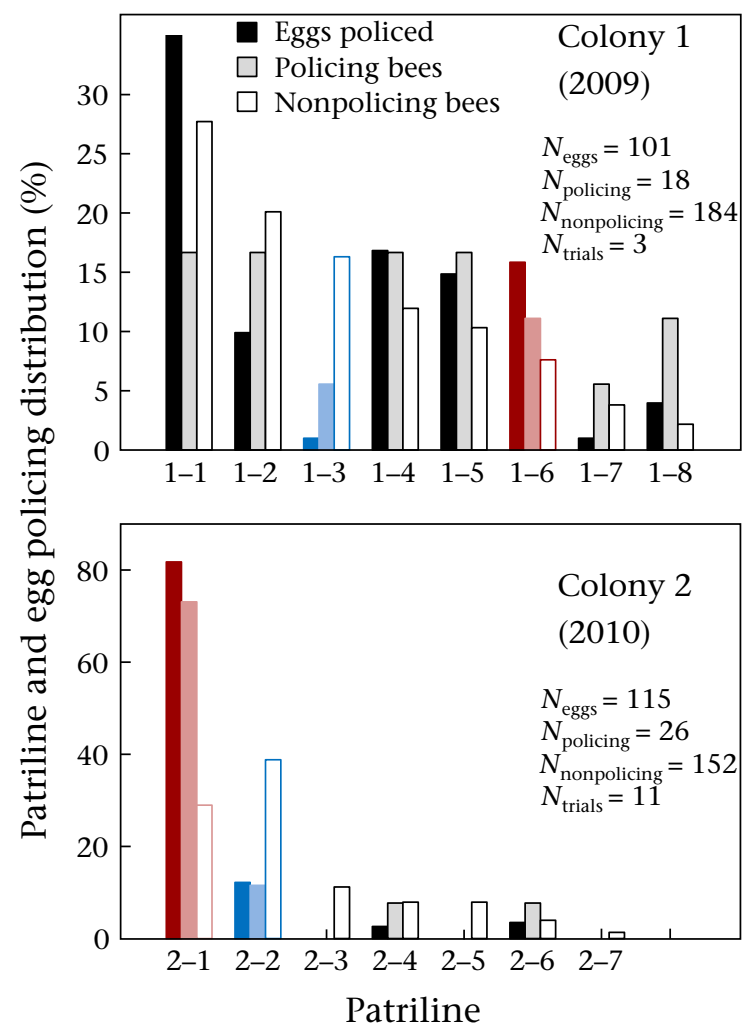

Figure 2. Genetic patriline specialization in policing behaviour. Patrilines that policed more than could be expected from their numerical abundance in the colony are indicated in red and those that policed less than expected are indicated in blue.

after which the sample was incubated for $15 \mathrm{~min}$ at $95^{\circ} \mathrm{C}$. Subsequently, samples were centrifuged for $10 \mathrm{~min}$ at 13000 relative centrifugal force. Eight microsatellite loci were amplified in two multiplex reactions using primers targeting four loci each (set 1: loci Am005, Am43, Am56, Am107; set 2: Am46, Am59, Am98, Am125, Solignac et al., 2003), using $0.2 \mu \mathrm{M}$ final concentration for each of the primers. PCR reactions were performed using a touchdown programme in $10 \mu \mathrm{l}$ volumes, using $5 \mu \mathrm{l}$ master mix (Qiagen multiplex PCR kit), $3 \mu \mathrm{l}$ milliQ water, $1 \mu$ primer mix and $1 \mu \mathrm{l}$ crude DNA-extract. Primers were fluorescently labelled with VIC, PET, NED and FAM (Applied Biosystems, Foster City, CA, U.S.A.). PCR conditions for the first multiplex reaction were as follows: initial denaturation at $95{ }^{\circ} \mathrm{C}$ for $15 \mathrm{~min}$; 10 cycles of $30 \mathrm{~s}$ at $94{ }^{\circ} \mathrm{C}, 90 \mathrm{~s}$ at $60^{\circ} \mathrm{C}$ and $90 \mathrm{~s}$ at $72^{\circ} \mathrm{C}$, whereby the annealing temperature was reduced by $0.2^{\circ} \mathrm{C}$ at each cycle; 25 cycles of $30 \mathrm{~s}$ at $94{ }^{\circ} \mathrm{C}, 90 \mathrm{~s}$ at $58^{\circ} \mathrm{C}, 90 \mathrm{~s}$ at $72{ }^{\circ} \mathrm{C}$; a final extension of $10 \mathrm{~min}$ at $72^{\circ} \mathrm{C}$. The second multiplex reaction was similar, except that the annealing temperature decreased from $62{ }^{\circ} \mathrm{C}$ to $60^{\circ} \mathrm{C}$ in the first 10 cycles, and was set to $60{ }^{\circ} \mathrm{C}$ for the next 25 cycles. PCR products of the two multiplex reactions were run together on an ABI-3130 Avant capillary sequencer by mixing $1 \mu \mathrm{l}$ of each PCR reaction, $7.8 \mu \mathrm{l}$ formamide and $0.2 \mu \mathrm{l}$ Genescan 500 LIZ size standard (Applied Biosystems) and were analysed using the GeneMapper software (Applied Biosystems). Patrilines were assigned manually. We estimated the nonsampling error (NSE, i.e. the probability of missing a patriline because it was not sampled) and the nondetection error (NDE, i.e. the probability of missing a patriline because it was indistinguishable from another patriline with the markers used) following Boomsma and Ratnieks (1996). More specifically, NSE $=(1-p)^{n}$ with $n=$ sample size and $p=$ proportion of workers sired by the undetected male, and $N D E=\prod_{j}^{k} \sum_{i}^{k}\left(q_{i}\right)^{2}$ with $q_{i}=$ the proportion of the $i^{\text {th }}$ allele of the $j^{\text {th }}$ genetic marker. Following Starr (1984), we estimated the effective paternity as $M_{e}=1 / \sum_{i}^{k} p_{i}^{2}$ with $p_{i}=$ the proportion of the workers genotyped derived from the $i^{\text {th }}$ father.

\section{Tests for Genetic and Individual Specialization in Policing Behaviour}

Genetic patriline specialization in policing behaviour was tested in two ways. First, we used two-way Fisher's exact tests to compare the distribution of the total number of eggs eaten by bees belonging to different patrilines across all trials with the patriline distribution of the genotyped nonpolicing control workers (Fig. 2). Second, more formally, we estimated the significance of the betweenpatriline variation in the numbers of workers of different patrilines that were observed to police based on a nested binomial GLMM with patriline nested within colony, after which the significance of the between-patriline variation was evaluated on the basis of a likelihood ratio test. From this model, we were then able to formally infer the broad-sense heritability of policing behaviour as twice the intraclass correlation coefficient (ICC), where the ICC was given as the between-patriline variance in ovary activation divided by the sum of the between-patriline variance, the betweencolony variance and the error variance, which in a logistic GLMM is equal to $\pi^{2} / 3$ (Bargum, Boomsma, \& Sundström, 2004; Snijders \& Bosker, 2012). The $95 \%$ confidence limits on the heritability were calculated using parametric bootstrapping with the lme4 bootMer function in R. Individual specialization in policing behaviour was assessed based on the significance of the variation within patrilines for individuals to police eggs, evaluated using a likelihood ratio test. This analysis was performed using a binomial GLMM, fitted using lme4, in which we analysed the proportion of eggs eaten by a particular individual within each trial out of all eggs eaten by known and genotyped individuals, coding colony, patriline, trial and individual as nested random effects. Age specialization was evaluated graphically by plotting the age distributions of policing and nonpolicing control workers (summing data from individuals that policed in different trials), and comparing the observed age ranges to those that have been reported for other types of tasks carried out inside honeybee colonies (Winston, 1987).

\section{RESULTS}

\section{Description of Policing Behaviour}

Policing behaviour was readily observed from the disappearance of eggs in our videos as well as from the fact that the policing of eggs took significantly longer than inspecting cells with eggs that were not policed or inspecting empty cells (Fig. 1c; gamma GLMM with Tukey post hoc tests: duration to police an egg versus not policing it: $z=3.76, P<0.001$; duration to police an egg versus inspecting an empty cell: $z=5.90, P<0.001$; see Supplementary material 2). Bee age did not affect the duration to inspect cells or police eggs (GLMM: $t=1.21, P=0.23$ ). As expected, policing was significantly directed against worker-laid eggs, even if some queenlaid eggs could also be removed by mistake (cf. Kärcher \& Ratnieks, 2014; Ratnieks \& Visscher, 1989; colony 1: 77/330 queen-laid eggs versus 15/330 worker-laid eggs survived after 12-24 h; two-tailed Fisher's exact test: $P=1.14 \times 10^{-12}$; colony $2: 250 / 477$ worker-laid eggs were removed within $2 \mathrm{~h}$ versus $164 / 485$ queen-laid eggs; two-tailed Fisher's exact test: $P=6.27 \times 10^{-9}$ ). At the individual level, most bees removed both worker-laid eggs and queen-laid eggs. However, as reported earlier (Ratnieks, 1990), eggs were often not removed on the first visit to the cell.

Bees that removed eggs usually entered a cell with their head and thorax. Bees did not always immediately back out of the cell 
when an egg was removed, but sometimes stayed in the cell for another $20 \mathrm{~s}$. On three occasions, two workers removed eggs with their head hardly inserted into the cell. Probably, the bees reached the egg using their tongue, and then transported it to their mouth. Bees that ate an egg sometimes cleaned their tongue and/or antennae afterwards but more often they moved directly into an adjacent cell. Occasionally, bees rotated inside a cell (ca. $180^{\circ}$, rarely $360^{\circ}$ or more), yet this was observed with and without egg removal. Most of the time, bees kept their wings folded back; in rare instances, bees entered cells with their wings half open. Occasionally, their hind legs did not grasp the comb but rather hung loosely when entering a cell. On one occasion, a worker licked the base of the cell around the egg, occasionally touching the egg with her forehead, but without removing the egg. Another worker worked on the wall of a cell before finally removing an egg. In rare cases, egg removal could be very fast $(<2 s)$, and one worker was observed to remove three eggs in only $24 \mathrm{~s}$, spending 2,3 and $7 \mathrm{~s}$ in the cells. Conversely, bees sometimes also remained in cells after they had removed an egg. Thus, the variance within and between workers was high.

Over the course of the experiments (total observation time: $28 \mathrm{~h}$ ), no worker was observed laying eggs, which is to be expected given that in the honeybee, only ca. one in 10000 workers develop their ovaries in the presence of the queen (Ratnieks, 1993). We can therefore safely conclude that policing behaviour was not aimed at obtaining direct reproductive benefits.

\section{Genetic Patriline Specialization in Policing}

We detected eight patrilines in colony 1 and seven in colony 2 and effective paternities, $M_{e}$, were 5.88 and 4.17, respectively, which is similar to the reported averages for honeybees (Tarpy, Nielsen, \& Nielsen, 2004). The nonsampling error for a patriline contributing $10 \%, 5 \%$ or $1 \%$ to the worker population in our colonies was $5.71 \times 10^{-10}, 3.16 \times 10^{-5}$ and 0.13 , respectively, in $2009(N=202)$, and $7.16 \times 10^{-9}, 1.08 \times 10^{-4}$ and 0.17 , respectively, in 2010 $(N=178)$. The nondetection error was 0.0097 in 2009 and 0.0015 in 2010. As expected if variation in policing behaviour is genetically heritable, there was a significant difference between the distribution of the number of eggs policed by workers belonging to different patrilines and the background patriline distribution in the colony among nonpolicing workers (Fig. 2; two-tailed Fisher's exact tests: $P=1.95 \times 10^{-5}$ and $P<2.20 \times 10^{-16}$ for colonies 1 and 2 ; see Supplementary material 3 ). By contrast, there was no significant difference between the distribution of the number of eggs policed and the patriline distribution of the genotyped policing workers (Fig. 2; two-tailed Fisher's exact tests: $P=0.18$ and $P=0.30$ for colonies 1 and 2). A more formal binomial GLMM analysis of the proportion of genotyped workers that were observed to police eggs across the different patrilines in both colonies confirmed that there was highly significant between-patriline variation in the tendency for bees of the different patrilines to engage in policing (likelihood ratio test: $\left.\chi^{2}=11.70, P=0.0006\right)$, resulting in a broad-sense heritability of the trait of 0.25 ([0.013, 0.46] 95\% confidence limits).

\section{Individual Specialization in Policing}

Our second binomial GLMM, in which we analysed quantitative variation in the proportion of eggs that were eaten by each worker out of all eggs eaten by genotyped individuals in each trial, showed that, in addition to significant patriline variation (likelihood ratio test: $\left.\chi^{2}=1582.7, \quad P<2.20 \times 10^{-16}\right)$, there was also significant between-individual variation in the number of eggs policed by different individuals within each patriline (likelihood ratio test: $\left.\chi^{2}=1433.6, P<2.20 \times 10^{-16}\right)$. In colony 1 , for example, only between one and three workers were observed policing eggs within each patriline, whereas in colony 2 between 0 and 19 individual workers were seen to police eggs across the different patrilines (Fig. 2; see Supplementary material 4). Hence, both genetic patriline and individual specialization in policing co-occur with each other.

\section{Age Profile of Policing Workers}

In 2009, bees that policed eggs were on average 22.9 (SD 7.3) days old $(N=36$, range $10-34$ days), whereas control nonpolicing bees were on average 25.2 (SD 7.7) days old ( $N=183$, range 3-45 days). In 2010, policing bees were on average 25.1 (SD 9.2) days old ( $N=45$, range 19-38 days), whereas control nonpolicing bees were on average 26.0 (SD 8.3) days old ( $N=759$, range $3-48$ days). As workers of all ages except those younger than 10 days and older than ca. 40 days engaged in policing, these results show that there was little evidence for age specialization in policing (Fig. 3a). This contrasts with most other behaviours in the honeybee, which usually follow a strict age-linked pattern of division of labour. The overall age profile of policing bees was perhaps most similar in profile to that recorded in the literature for bees that patrol the nest, and which may well have been the term used for cell inspection and policing in studies where worker-laid eggs were not experimentally introduced into the nest, and policing could therefore not be directly observed (Winston, 1987; Fig. 3b).

\section{DISCUSSION}

Worker policing by egg eating is an important means of regulating reproductive conflict in social insect colonies. Our behavioural observations and patriline analyses of worker policing behaviour in the honeybee showed for the first time that there was significant genetic specialization in policing, as demonstrated by the significant variation in policing across patrilines and our estimate of a moderate genetic heritability of policing of 0.25 . These results, therefore, confirm that genes coding for worker policing behaviour would be able to readily spread in populations via the indirect genetic transmission of copies of these genes through relatives, as originally envisioned (Ratnieks, 1988; Starr, 1984). The fact that no single worker egg-laying event was observed also clearly demonstrates that worker policing is not aimed at obtaining direct reproductive benefits, unlike what has been observed in some species (Bonckaert et al., 2011; Saigo \& Tsuchida, 2004; Stroeymeyt et al., 2007; Wenseleers, Badcock et al., 2005). However, the fact that our heritability estimate was relatively low, and similar in magnitude to that typically observed for other behavioural traits in honeybees (e.g. hygienic behaviour towards dead brood: 0.17-0.25; Pernal et al., 2012), shows that worker policing is probably not controlled by genes of large effect, and that recent theoretical analyses of worker policing that focused on the evolution of this trait via genes of large effect (Olejarz, Allen, Veller, Gadagkar, \& Nowak, 2016) are therefore unrealistic. The notion that worker policing probably evolved through gradual evolution via the successive invasion of mutations of relatively small effect also supports inclusive fitness theory, as weak selection is usually an underlying assumption of most such analyses (Nowak, Tarnita, \& Wilson, 2010; Wenseleers, 2006).

Previously, patriline specialization has been reported for many other honeybee behaviours (reviewed in Robinson, 1992). It is expected in response threshold models of division of labour when different genetically determined thresholds determine the likelihood of performing a given task (Beshers \& Fewell, 2001; Lattorff \& Moritz, 2013). However, thresholds are influenced not only by genes, but also by ontogeny (development), physiology (hormones), 
(a)

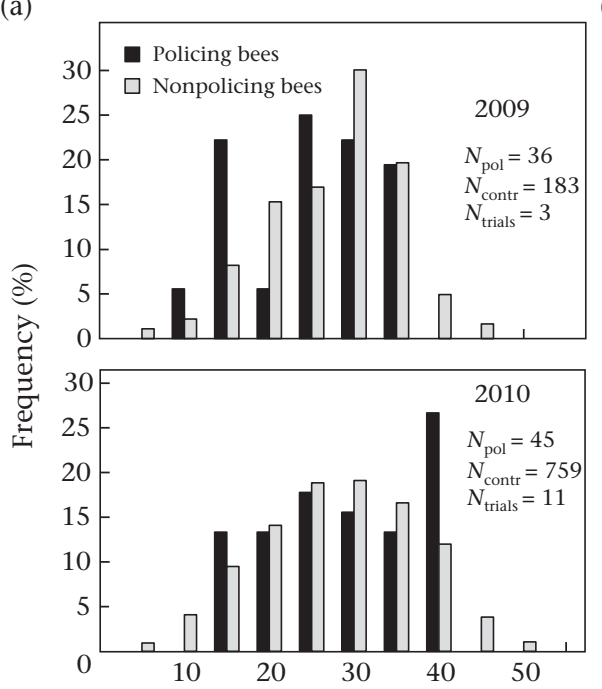

(b)

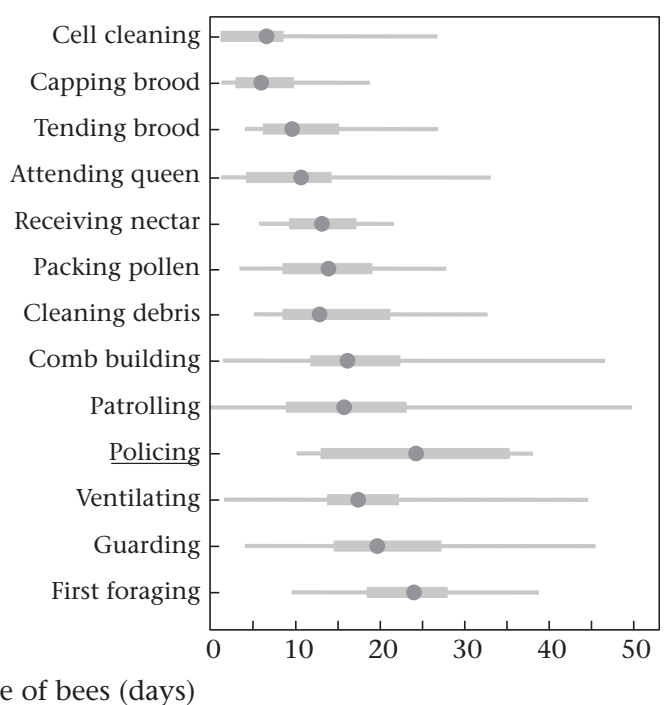

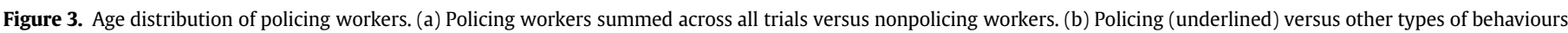
reported in European honeybees (data from Winston, 1987 and this study; thin black line = range, thick grey bars $=$ common range).

experience and other factors that modulate individual motivation (Beshers \& Fewell, 2001; Duarte et al., 2011; Jeanson \& Weidenmüller, 2014). For instance, learning and selfreinforcement have been shown to lead to specialization. The strong evidence we found for individual specialization in worker policing, whereby only a limited number of individuals carried out policing behaviour within each patriline, suggests that this variation is driven by such feedbacks.

Finally, we found little evidence for age specialization in policing behaviour, as workers of nearly all ages, except those younger than 10 days and older than 40 days, engaged in egg policing. This result was surprising, as for most other behaviours in the honeybee, there is typically a strongly age-linked pattern of expression (Seeley, 1982; Winston, 1987). That no bees younger than 10 days were observed policing eggs could be explained by such young bees being found mostly in the centre of the brood nest where they are engaged in cleaning cells and brood care (Johnson, 2008; Kolmes, 1986; Seeley \& Kolmes, 1991; Seeley, 1982; Winston, 1987), and by our experimental comb being introduced above the brood nest. As to why there was no stronger age specialization there are several possibilities. One may be that worker policing behaviour could easily be carried out by other workers of different ages that carry out other tasks inside the colony while working on the combs for other reasons, for example to clean cells, receive nectar or pack pollen, build comb or patrol the nest (Fig. $3 \mathrm{~b}$ ), and that switching to carrying out policing behaviour could therefore entail only a small cost for workers of any age (Goldsby et al., 2012; Leighton, Charbonneau, \& Dornhaus, 2016). In our current study, however, we were unable to test whether workers engaged in policing also regularly switched to carrying out other tasks or not. Another possibility is that the age profile of policing bees corresponds to that for bees that engage in patrolling and cell inspection (Johnson, 2008), which is typically carried out with equal efficiency by bees of different age classes (Fig. 3b).

In general, individual experience can increase the chance of performing a task (e.g. Chittka \& Muller, 2009; Ravary, Lecoutey, Kaminski, Châline, \& Jaisson, 2007; Van Wilgenburg, Clémencet, \& Tsutsui, 2010). Thus, bees that have removed an egg might be more likely to remove another egg. This does not imply that bees that remove eggs are better at discriminating between queen-laid eggs and worker-laid eggs, although it would seem plausible that learning through increased experience eventually leads to better and/or faster discrimination. In this study, we introduced a relatively large number of worker-laid eggs (33-69) at a high concentration (in fewer than 170 cells). It has been estimated that in a large bee colony (of 30-40 000 bees), ca. 15-40 worker-laid eggs per day are deposited (Visscher, 1996); in our observation hives, ca. 3000 bees were present, suggesting that only one to three workerlaid eggs would be deposited per day, thereby explaining why no worker egg-laying event was observed. The fact that so few eggs are laid by workers, and that only few workers seem to be able to effectively remove nearly all worker-laid eggs, probably explains why only so few honeybee workers engage in worker policing.

We hope that our work will inspire further follow-up studies, for example aimed at characterizing the gene regulatory networks involved in worker policing behaviour or identifying the eggmarking signal that allows workers to distinguish between queenlaid and worker-laid eggs, and which, unlike in wasps (Oi et al., 2015), remains enigmatic (Martin, Châline, Ratnieks, \& Jones, 2005).

\section{Acknowledgments}

This work was supported by the Agency for Innovation by Science and Technology in Flanders (IWT) [U.E. and D.C.] and the Research Foundation Flanders (FWO) (G.0417.08). P.V. was an FWO postdoctoral scholar. We thank J. Bamps, B. Bauwens, N. Bourgeois, S. Deroover, G. Detienne, A. Lamon, A. Maes and A. Roose for their contributions to the data analysis, N. Ernst for help with the figures and B. Hellemans for help with microsatellite analysis. Special thanks are due to W. Bonckaert, A. Vantaux, N. Vantaux and V. Vantaux for their help in marking bees. We acknowledge the support of the Information Centre for Beekeeping (Ghent), especially D. Laget and J. Eerens, and the help of members of the Laboratory of Zoophysiology (Ghent) and members of the Animal Physiology section (Leuven).

\section{Supplementary Material}

Supplementary material associated with this article is available, in the online version, at http://dx.doi.org/10.1016/j.anbehav.2017. 04.005 . 


\section{References}

Bargum, K., Boomsma, J. J., \& Sundström, L. (2004). A genetic component to size in queens of the ant, Formica truncorum. Behavioral Ecology and Sociobiology, 57(1), 9-16. http://dx.doi.org/10.1007/s00265-004-0836-z.

Barth, M. B., Kellner, K., \& Heinze, J. (2010). The police are not the army: Contextdependent aggressiveness in a clonal ant. Biology Letters, 6(3), 329-332. http://dx.doi.org/10.1098/rsbl.2009.0849.

Beekman, M., \& Oldroyd, B. P. (2005). Honeybee workers use cues other than egg viability for policing. Biology Letters, 1(2), 129-132. http://dx.doi.org/10.1098/ rsbl.2005.0294.

Beekman, M., \& Oldroyd, B. P. (2008). When workers disunite: Intraspecific parasitism by eusocial bees. Annual Review of Entomology, 53, 19-37. http:/ dx.doi.org/10.1146/annurev.ento.53.103106.093515.

Beshers, S. N., \& Fewell, J. H. (2001). Models of division of labor in social insects. Annual Review of Entomology, 46(1), 413-440. http://dx.doi.org/10.1146/ annurev.ento.46.1.413.

Bonckaert, W., Tofilski, A., Nascimento, F. S., Billen, J., Ratnieks, F. L. W., \& Wenseleers, T. (2011). Co-occurrence of three types of egg policing in the Norwegian wasp Dolichovespula norwegica. Behavioral Ecology and Sociobiology, 65(4), 633-640. http://dx.doi.org/10.1007/s00265-010-1064-3.

Bonckaert, W., Vuerinckx, K., Billen, J., Hammond, R. L., Keller, L., \& Wenseleers, T. (2008). Worker policing in the German wasp Vespula germanica. Behavioral Ecology, 19(2), 272-278. http://dx.doi.org/10.1093/beheco/arm128.

Boomsma, J. J., \& Ratnieks, F. L. W. (1996). Paternity in Eusocial Hymenoptera. Philosophical Transactions of the Royal Society London: Biological Sciences, 351(1342), 947-975. http://dx.doi.org/10.1098/rstb.1996.0087.

Bourke, A. F. G. (2011). Principles of social evolution. Oxford, U.K.: Oxford University Press.

Calderone, N. W., \& Page, R. E. (1988). Genotypic variability in age polyethism and task specialization in the honey bee, Apis mellifera (Hymenoptera: Apidae). Behavioral Ecology and Sociobiology, 22(1), 17-25.

Chittka, L., \& Muller, H. (2009). Learning, specialization, efficiency and task allocation in social insects. Communicative \& Integrative Biology, 2(2), 151-154. http:/ dx.doi.org/10.4161/cib.7600.

D'Ettorre, P., Heinze, J., \& Ratnieks, F. L. W. (2004). Worker policing by egg eating in the ponerine ant Pachycondyla inversa. Proceedings of the Royal Society B: Biological Sciences, 271(1546), 1427-1434. http://dx.doi.org/10.1098/rspb.2004.2742.

Dampney, J. R., Barron, A. B., \& Oldroyd, B. P. (2002). Policing of adult honey bees with activated ovaries is error prone. Insectes Sociaux, 49(3), 270-274. http:/ dx.doi.org/10.1007/s00040-002-8313-z.

Dampney, J. R., Barron, A. B., \& Oldroyd, B. P. (2004). Measuring the cost of worke reproduction in honeybees: Work tempo in an 'anarchic' line. Apidologie, 35(1) 83-88. http://dx.doi.org/10.1051/apido:2003067.

Davies, N. B., Krebs, J. R., \& West, S. A. (2012). An introduction to behavioural ecology. Chichester, U.K.: J. Wiley.

Dijkstra, M. B., van Zweden, J. S., Dirchsen, M., \& Boomsma, J. J. (2010). Workers of Acromyrmex echinatior leafcutter ants police worker-laid eggs, but not reproductive workers. Animal Behaviour, 80(3), 487-495. http://dx.doi.org/10.1016/ j.anbehav.2010.06.011.

Duarte, A., Weissing, F. J., Pen, I., \& Keller, L. (2011). An evolutionary perspective on self-organized division of labor in social insects. Annual Review of Ecology, Evolution, and Systematics, 42(1), 91-110. http://dx.doi.org/10.1146/annurevecolsys-102710-145017.

Dugatkin, L. A. (2009). Principles of animal behavior (2nd ed.). New York, NY: W. W. Norton.

Foster, K. R., \& Ratnieks, F. L. W. (2001a). Convergent evolution of worker policing by egg eating in the honeybee and common wasp. Proceedings of the Royal Society B: Biological Sciences, 268(1463), 169-174.

Foster, K. R., \& Ratnieks, F. L. W. (2001b). The effect of sex-allocation biasing on the evolution of worker policing in hymenopteran societies. American Naturalist, 158(6), 615-623. http://dx.doi.org/10.1086/323588.

Frank, S. A. (2003). Repression of competition and the evolution of cooperation. Evolution, 57(4), 693-705.

Goldsby, H. J., Dornhaus, A., Kerr, B., \& Ofria, C. (2012). Task-switching costs promote the evolution of division of labor and shifts in individuality. Proceedings of the National Academy of Sciences of the United States of America, 109(34) 13686-13691. http://dx.doi.org/10.1073/pnas.1202233109.

Hamilton, W. D. (1964). Genetical evolution of social behaviour I \& II. Journal of Theoretical Biology, 7(1), 1-52. http://dx.doi.org/10.1016/0022-5193(64)90038-4.

Helanterä, H., Tofilski, A., Wenseleers, T., \& Ratnieks, F. L. W. (2006). Worker policing in the common wasp Vespula vulgaris is not aimed at improving colony hygiene. Insectes Sociaux, 53(4), 399-402. http://dx.doi.org/10.1007/ s00040-005-0885-6.

Hellmich, R. L., Kulincevic, J. M., \& Rothenbuhler, W. C. (1985). Selection for high and low pollen-hoarding honey bees. Journal of Heredity, 76(3), 155-158.

Hunt, G. J., Page, R., Fondrk, M. K., \& Dullum, C. J. (1995). Major quantitative trait loci affecting honey bee foraging behavior. Genetics, 141(4), 1537-1545.

Jeanson, R., \& Weidenmüller, A. (2014). Interindividual variability in social insects proximate causes and ultimate consequences. Biological Reviews, 89(3), 671-687. http://dx.doi.org/10.1111/brv.12074.

Johnson, B. R. (2008). Within-nest temporal polyethism in the honey bee. Behaviora Ecology and Sociobiology, 62(5), 777-784. http://dx.doi.org/10.1007/s00265007-0503-2.
Johnson, B. R. (2010). Division of labor in honeybees: Form, function, and proximate mechanisms. Behavioral Ecology and Sociobiology, 64(3), 305-316. http:/ dx.doi.org/10.1007/s00265-009-0874-7.

Kärcher, M. H., \& Ratnieks, F. L. W. (2014). Killing and replacing queen-laid eggs: Low cost of worker policing in the honeybee. American Naturalist, 184(1), 110-118. http://dx.doi.org/10.1086/676525.

Kolmes, S. A. (1986). Age polyethism in worker honey bees. Ethology, 71(3), 252-255. http://dx.doi.org/10.1111/j.1439-0310.1986.tb00589.x.

Lattorff, H. M. G., \& Moritz, R. F. A. (2013). Genetic underpinnings of division of labor in the honeybee (Apis mellifera). Trends in Genetics, 29(11), 641-648. http:// dx.doi.org/10.1016/j.tig.2013.08.002.

Leighton, G. M., Charbonneau, D., \& Dornhaus, A. (2016). Task switching is associated with temporal delays in Temnothorax rugatulus ants. Behavioral Ecology, arw162. http://dx.doi.org/10.1093/beheco/arw162.

Martin, S. J., Châline, N. G., Ratnieks, F. L. W., \& Jones, G. R. (2005). Searching for the egg-marking signal in honeybees. Journal of Negative Results-Ecology \& Evolutionary Biology, 2(1), 1-9.

Maynard Smith, J., \& Szathmary, E. R. (1995). The major transitions in evolution. Oxford, U.K.: W.H. Freeman.

Naeger, N. L., Peso, M., Even, N., Barron, A. B., \& Robinson, G. E. (2013). Altruistic behavior by egg-laying worker honeybees. Current Biology, 23(16), 1574-1578. http://dx.doi.org/10.1016/j.cub.2013.06.045.

Nowak, M. A., Tarnita, C. E., \& Wilson, E. O. (2010). The evolution of eusociality. Nature, 466(7310), 1057-1062. http://dx.doi.org/10.1038/nature09205.

Ohtsuki, H., \& Tsuji, K. (2009). Adaptive reproduction schedule as a cause of worker policing in social hymenoptera: A dynamic game analysis. American Naturalist, 173(6), 747-758. http://dx.doi.org/10.1086/59848.

Oi, C. A., Van Oystaeyen, A., Oliveira, R. C., Millar, J. G., Verstrepen, K. J., van Zweden, J. S., et al. (2015). Dual effect of wasp queen pheromone in regulating insect sociality. Current Biology, 25(12), 1638-1640. http://dx.doi.org/10.1016/ j.cub.2015.04.040.

Oldroyd, B. P., \& Fewell, J. H. (2007). Genetic diversity promotes homeostasis in insect colonies. Trends in Ecology \& Evolution, 22(8), 408-413. http://dx.doi.org/ 10.1016/j.tree.2007.06.001.

Oldroyd, B. P., Halling, L. A., Good, G., Wattanachaiyingcharoen, W., Barron, A. B., Nanork, P., et al. (2001). Worker policing and worker reproduction in Apis cerana. Behavioral Ecology and Sociobiology, 50(4), 371-377. http://dx.doi.org/ $10.1007 / \mathrm{s} 002650100376$.

Oldroyd, B. P., \& Thompson, G. J. (2006). Behavioural genetics of the honey bee Apis mellifera. Advances in Insect Physiology, 33, 1-49.

Olejarz, J. W., Allen, B., Veller, C., Gadagkar, R., \& Nowak, M. A. (2016). Evolution of worker policing. Journal of Theoretical Biology, 399, 103-116. http://dx.doi.org/ 10.1016/j.jtbi.2016.03.001.

Oxley, P. R., Spivak, M., \& Oldroyd, B. P. (2010). Six quantitative trait loci influence task thresholds for hygienic behaviour in honeybees (Apis mellifera). Molecular Ecology, 19(7), 1452-1461.

Pernal, S. F., Sewalem, A., \& Melathopoulos, A. P. (2012). Breeding for hygienic behaviour in honeybees (Apis mellifera) using free-mated nucleus colonies. Apidologie, 43(4), 403-416. http://dx.doi.org/10.1007/s13592-011-0105-X.

Pirk, C. W. W., Neumann, P., \& Hepburn, R. (2007). Nestmate recognition for eggs in the honeybee (Apis mellifera L.). Behavioral Ecology and Sociobiology, 61(11), 1685-1693. http://dx.doi.org/10.1007/s00265-007-0399-x.

Pirk, C. W. W., Neumann, P., Hepburn, R., Moritz, R. F. A., \& Tautz, J. (2004). Egg viability and worker policing in honey bees. Proceedings of the National Academy of Sciences of the United States of America, 101(23), 8649-8651. http://dx.doi.org/ 10.1073/pnas.0402506101.

Queller, D. C., \& Strassmann, J. E. (2009). Beyond society: The evolution of organismality. Philosophical Transactions of the Royal Society B: Biological Sciences, 364(1533), 3143-3155. http://dx.doi.org/10.1098/rstb.2009.0095.

Rainey, P. B., \& De Monte, S. (2014). Resolving conflicts during the evolutionary transition to multicellular life. Annual Review of Ecology, Evolution, and Systematics, 45, 599-620. http://dx.doi.org/10.1146/annurev-ecolsys-120213091740.

Ratnieks, F. L. W. (1988). Reproductive harmony via mutual policing by workers in eusocial Hymenoptera. American Naturalist, 132(2), 217-236. http://dx.doi.org/ $10.1086 / 284846$.

Ratnieks, F. L. W. (1990). Worker policing in social insects. In G. K. Veeresh, B. Mallik, \& C. A. Viraktamath (Eds.), Social insects and the environment. Proceedings of the 11th International Congress of IUSSI, 1990 (International Union for the Study of Social Insects) (pp. 365-366). Leiden, The Netherlands: E.J. Brill.

Ratnieks, F. L. W. (1993). Egg-laying, egg-removal, and ovary development by workers in queenright honey bee colonies. Behavioral Ecology and Sociobiology, 32(3), 191-198. http://dx.doi.org/10.1007/BF00173777.

Ratnieks, F. L. W., Foster, K. R., \& Wenseleers, T. (2006). Conflict resolution in insect societies. Annual Review of Entomology, 51, 581-608. http://dx.doi.org/10.1146/ annurev.ento.51.110104.151003.

Ratnieks, F. L. W., \& Visscher, P. K. (1989). Worker policing in the honeybee. Nature, 342(6251), 796-797. http://dx.doi.org/10.1038/342796a0.

Ratnieks, F. L. W., \& Wenseleers, T. (2008). Altruism in insect societies and beyond: Voluntary or enforced? Trends in Ecology \& Evolution, 23(1), 45-52. http:// dx.doi.org/10.1016/j.tree.2007.09.013.

Ravary, F., Lecoutey, E., Kaminski, G., Châline, N., \& Jaisson, P. (2007). Individual experience alone can generate lasting division of labor in ants. Current Biology, 17(15), 1308-1312. http://dx.doi.org/10.1016/j.cub.2007.06.047. 
Robinson, G. E. (1992). Regulation of division of labor in insect societies. Annual Review of Entomology, 37(1), 637-665. http://dx.doi.org/10.1146/ annurev.en.37.010192.003225.

Robinson, G. E., \& Page, R. E. (1988). Genetic determination of guarding and undertaking in honey-bee colonies. Nature, 333(6171), 356-358. http://dx.doi.org/ $10.1038 / 333356 a 0$

Robinson, G. E., \& Page, R. E. (1989). Genetic determination of nectar foraging, pollen foraging, and nest-site scouting in honey bee colonies. Behavioral Ecology and Sociobiology, 24(5), 317-323.

Saigo, T., \& Tsuchida, K. (2004). Queen and worker policing in monogynous and monandrous colonies of a primitively eusocial wasp. Proceedings of the Royal Society B: Biological Sciences, 271, S509-S512. http://dx.doi.org/10.1098/ rsbl.2004.0238.

Seeley, T. D. (1982). Adaptive significance of the age polyethism schedule in honeybee colonies. Behavioral Ecology and Sociobiology, 11(4), 287-293. http:// dx.doi.org/10.1007/bf00299306.

Seeley, T. D. (1995). The wisdom of the hive: The social physiology of honey bee $\mathrm{col}$ onies. Cambridge, Mass.; London: Harvard University Press.

Seeley, T. D., \& Kolmes, S. A. (1991). Age polyethism for hive duties in honey bees illusion or reality? Ethology, 87(3-4), 284-297. http://dx.doi.org/10.1111/j.14390310.1991.tb00253.x.

Smith, C. R., Toth, A. L., Suarez, A. V., \& Robinson, G. E. (2008). Genetic and genomic analyses of the division of labour in insect societies. Nature Reviews Genetics, 9(10), 735-748. http://dx.doi.org/10.1038/nrg2429.

Snijders, T. A. B., \& Bosker, R. J. (2012). Multilevel analysis: An introduction to basic and advanced multilevel modeling (2nd ed.). Los Angeles, CA: Sage.

Solignac, M., Vautrin, D., Loiseau, A., Mougel, F., Baudry, E., Estoup, A., et al. (2003). Five hundred and fifty microsatellite markers for the study of the honeybee (Apis mellifera L.) genome. Molecular Ecology Notes, 3(2), 307-311. http:// dx.doi.org/10.1046/j.1471-8286.2003.00436.x.

Starr, C. K. (1984). Sperm competition, kinship, and sociality in the Aculeate Hymenoptera. In R. L. Smith (Ed.), Sperm competition and the evolution of animal mating systems (pp. 427-464). London, U.K.: Academic Press.

Stroeymeyt, N., Brunner, E., \& Heinze, J. (2007). 'Selfish worker policing' controls reproduction in a Temnothorax ant. Behavioral Ecology and Sociobiology, 61(9), 1449-1457. http://dx.doi.org/10.1007/s00265-007-0377-3.

Taber, S. (1961). Forceps design for transferring honey bee eggs. Journal of Economic Entomology, 54(2), 247-250. http://dx.doi.org/10.1093/jee/54.2.247.

Tarpy, D. R., Nielsen, R., \& Nielsen, D. (2004). A scientific note on the revised estimates of effective paternity frequency in Apis. Insectes Sociaux, 51(2), 203-204. http://dx.doi.org/10.1007/s00040-004-0734-4.

Trumbo, S. T., Huang, Z.-Y., \& Robinson, G. E. (1997). Division of labor between undertaker specialists and other middle-aged workers in honey bee colonies. Behavioral Ecology and Sociobiology, 41(3), 151-163. http://dx.doi.org/10.1007/ s002650050374.

Van Wilgenburg, E., Clémencet, J., \& Tsutsui, N. D. (2010). Experience influences aggressive behaviour in the Argentine ant. Biology Letters, 6(2), 152-155. http:/ dx.doi.org/10.1098/rsbl.2009.0616. van Zweden, J. S., Fürst, M. A., Heinze, J., \& D'Ettorre, P. (2007). Specialization in policing behaviour among workers in the ant Pachycondyla inversa. Proceedings of the Royal Society B: Biological Sciences, 274(1616), 1421-1428. http:/| dx.doi.org/10.1098/rspb.2007.0113.

Visscher, P. K. (1996). Reproductive conflict in honey bees: A stalemate of worker egg-laying and policing. Behavioral Ecology and Sociobiology, 39(4), 237-244. http://dx.doi.org/10.1007/s002650050286.

Visscher, P. K., \& Dukas, R. (1995). Honey bees recognize development of nestmates' ovaries. Animal Behaviour, 49(2), 542-544. http://dx.doi.org/10.1006/ anbe.1995.0074.

Walsh, P. S., Metzger, D. A., \& Higuchi, R. (1991). Chelex 100 as a medium for simple extraction of DNA for PCR-based typing from forensic material. Biotechniques, 10(4), 506-513. http://dx.doi.org/10.2144/000114018.

Wenseleers, T. (2006). Modelling social evolution: The relative merits and limitations of a Hamilton's rule-based approach. Journal of Evolutionary Biology, 19(5) $1419-1422$.

Wenseleers, T., Badcock, N. S., Erven, K., Tofilski, A., Nascimento, F. S., Hart, A. G. et al. (2005). A test of worker policing theory in an advanced eusocial wasp Vespula rufa. Evolution, 59(6), 1306-1314.

Wenseleers, T., Hart, A. G., \& Ratnieks, F. L. W. (2004). When resistance is useless: Policing and the evolution of reproductive acquiescence in insect societies. American Naturalist, 164(6), E154-E167. http://dx.doi.org/10.1086/425223.

Wenseleers, T., Helantera, H., Alves, D. A., Duenez-Guzman, E., \& Pamilo, P. (2013). Towards greater realism in inclusive fitness models: The case of worker reproduction in insect societies. Biology Letters, 9(6)(7). http://dx.doi.org $10.1098 /$ rsbl.2013.0334.

Wenseleers, T., Helantera, H., Hart, A., \& Ratnieks, F. L. W. (2004). Worker reproduction and policing in insect societies: An ESS analysis. Journal of Evolutionary Biology, 17(5), 1035-1047. http://dx.doi.org/10.1111/j.14209101.2004.00751x.

Wenseleers, T., \& Ratnieks, F. L. W. (2006a). Comparative analysis of worker reproduction and policing in eusocial hymenoptera supports relatedness theory. American Naturalist, 168(6), E163-E179. http://dx.doi.org/10.1086 508619.

Wenseleers, T., \& Ratnieks, F. L. W. (2006b). Enforced altruism in insect societies. Nature, 444(7115), 50. http://dx.doi.org/10.1038/444050a.

Wenseleers, T., Tofilski, A., \& Ratnieks, F. L. W. (2005). Queen and worker policing in the tree wasp Dolichovespula sylvestris. Behavioral Ecology and Sociobiology, 58(1), 80-86. http://dx.doi.org/10.1007/s00265-004-0892-4.

Winston, M. L. (1987). The biology of the honey bee. Cambridge, MA: Harvard University Press.

Zanette, L. R. S., Miller, S. D. L., Faria, C. M. A., Almond, E. J., Huggins, T. J., Jordan, W. C., et al. (2012). Reproductive conflict in bumblebees and the evolution of worker policing. Evolution, 66(12), 3765-3777. http://dx.doi.org/ 10.1111/j.1558-5646.2012.01709.x. 